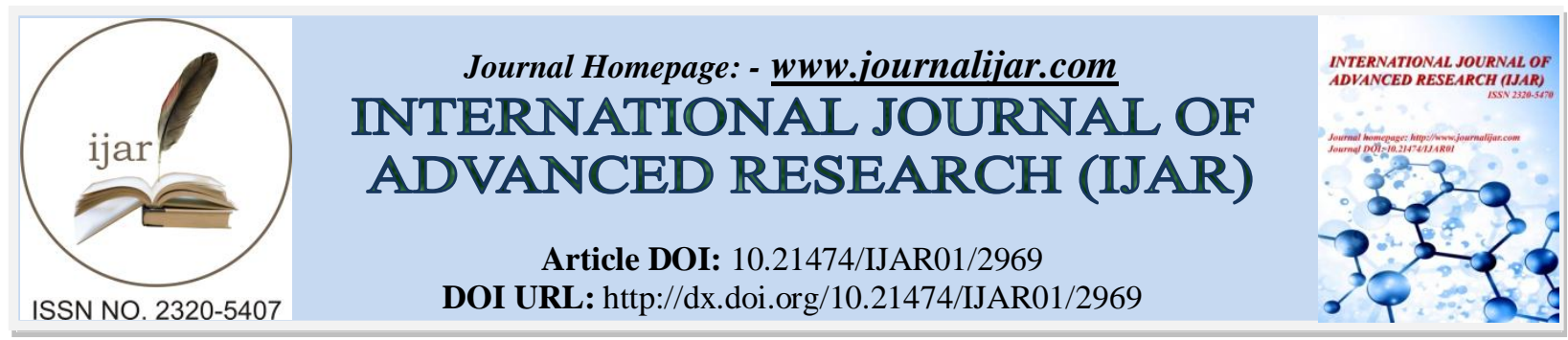

RESEARCH ARTICLE

\title{
COMPARATIVE STUDIES OF GENETIC VARIABILITY IN SOYBEAN (GLYCINE MAX. (L.) MERRILL) DERIVED GENOTYPES USING MOLECULAR MARKER.
}

Sanjay N. Pathare ${ }^{1}$ and Dr. Rajendra A. Satpute ${ }^{2}$.

1. Seed Testing Division, Department of Quality Assurance, Ajeet Seeds Pvt Ltd, Chitegaon, Aurangabad.

2. Department of Biotechnology, Government Institute of Science, Aurangabad.

\section{Manuscript Info}

Manuscript History

Received: 30 November 2016

Final Accepted: 26 December 2016

Published: January 2017

Key words:-

Genetic diversity, Glycine max,

Molecular markers, dendrogram.

\begin{abstract}
The vast Mutagenic effect showed by application of mutagens (Sodium Azide -3mM, 5mM, 7mM; Ethyl Methane Sulphonate $-5 \mathrm{mM}, 10 \mathrm{mM}$, $15 \mathrm{mM}$; And Gamma Irradiation -100kr, 200kr, 300kr).That clearly showed in field as well as laboratory testing; by using molecular markers, PCR (Polymerase chain reaction) ISSR( Inter Simple Sequence Repeat). Mutagenic variation founded in all the mutagens, but selected Genotypes were obtained from $100 \mathrm{kr}$ and $10 \mathrm{mM}$ Mutagenic lines. We demonstrate these genotypes for phenotypic screening and associated maturity, morphology, pigmentation traits. ISSR analysis done by two Primers and it was detected polymorphisms. For analysis, two primers were designed from consensus sequence regions on protein homolog genes, and used to amplify the genomic region. PCR samples were sequenced. The total number of polymorphic ISSR bands showed specific range and scored on all genotypes and their homology was measured.
\end{abstract}

Copy Right, IJAR, 2016,. All rights reserved.

\section{Introduction:-}

The genus Glycine consists of two subgenera, i.e. Glycine and Soja. Glycine max (L).Merr. And G.soja Sib. \& Zucc. Belongs to Soja subgenus. Glycine max is the cultivated soybean while Glycine Soja is its wild progenitor. Soybean (Glycine max (L) Merrill) is an important crop as a source of protein and oil. Charles and Morse (1923) reported that the origin of soybean is china, Manchuria and Korea. Soybean is one of the best valued crops for its ability to fix nitrogen and provide seed protein and oil. In this importance the species are needed to develop new strain by mutagenesis to prove key step for identifying gene function in cultivar. A number of mutagen sources exist for introducing genomic variation. These include chemical, radiation, and transformation-induced mutagenesis of plant genomes (Waugh et al; 2006; Kuromori et al; 2009).Each of these methods results in a signature footprint of structural variation across the genome (Alonso and Ecker, 2006).

Molecular markers have become new tools and technique to help reduces workers effort(in identifying genotypes, save time i.e. work performed in short period of time, in most plant breeding programme, including introduction, selection and certification. Among them, SSR also known as micro satellite or short tandem repeat or simple sequence length polymorphisms is a repeated nucleotide sequence of 2-7 base pair units. Repeatability of fragment resulted from slippage in replication ( Schlotterer and Tautz, 1992) and unequal crossover (Smith, 1976). The SSR technique uses PCR to amplify DNA fragments by repeated cycles of DNA denaturing, annealing and extension using DNA polymerase enzyme. The resulting DNA was separated by banding on gel (Akkaya et al; 1992).This 
method has many advantages such as rapid, reliable (Diwan and Cregan,1997), abundance (Lagerkrantz et al;1993),co-dominant(Akkaya et al;1992), high heterozygosity (Powell et al;1996), and high polymorphism(Akkaya et al;1995).

SSR has been used in the construction of genetic linkage map of human(Gyapay et al;1994), soybean shoe-marker Morgante, 1994; Akkaya et al;1995;Maughan et al;1995)and also used in DNA fingerprint of soybean (Yanagisawa et al;1994;Diwan and Cregan,1997).

SNP is single base variation between two identical DNA sequences. Brooks (1999) reported that SNP was single base pair positions in genomic DNA at which different sequence alternatives (alleles) exist in normal individuals of natural populations. This technology allows greater number of tests to be run at a significantly lower cost than existing technology. This technology has application in genome sequencing, SNP identification and typing, screening for genetically-linked diseases, identification of genetic drug targets, screening for individuals for potential drug side effects, gene cloning, screening potential tissue donors, screening cancer cells for genes conferring chemotherapy resistance. This technique has more advantages than markers such as isozyme, RFLP, RAPD, SSR. These advantages include very large number of polymorphic loci which distributed throughout the genome, marker present within coding regions, introns and regions that flank genes, simple and unambiguous assay techniques, high level of polymorphism in the population, stable Mendelian inheritance and low levels of spontaneous mutation (Brown, 1999).

Soybean genotypes were grown for said phenotypic characters indicating the different genetic variability among 12 genotypes. The objective of this study was to evaluate genetic variability and relationship among 12 soybean genotypes. by using PCR-ISSR .

\section{Materials and Methods:-}

Plant material and DNA isolation:-

Fresh seeds of soybean genotypes were used in this study for DNA extraction and isolation. The genotypes of soybean were grown in Aurangabad district (MS). The analyzed samples included dried soybean seeds that were used directly for DNA extraction. They found to yield DNA's comparable in quality and quantity when using EZI nucleic acid isolation analyzer (QIAGEN, 2007), CTAB method. Plant genomic DNA purification kit method, and DNA extraction with phenol purification and liquid nitrogen method, a soybean seed bulk sample was ground to fine powder. The experiment was carried out under the same conditions for all DNA samples.

\section{Molecular material:-}

DNA was extracted from seeds of soybean genotypes (Glycine max (L.) Merrill.) were grown in Aurangabad (MS) and isolated genomic DNA was amplified with two primers.

Table 1:- Primers for PCR amplification of Soybean (Glycine max (L.) Merrill.) Used in the study

\begin{tabular}{|c|c|c|c|}
\hline Primer & Annealing Tm & Primer bp & Primer Sequence \\
\hline SPA & $54^{\circ} \mathrm{c}$ & 320 & 5'-CCACTATCCTTCGCAAGACCCTTCC-3' \\
\hline SPB & $54^{\circ} \mathrm{c}$ & 320 & 5'CTTCTGTGCTGTAGCCACTGATGC-3' \\
\hline LE5 & $53^{\circ} \mathrm{c}$ & 180 & 5'-TCAACGAAAACGAGTCTGGTG-3' \\
\hline LE6 & $53^{\circ} \mathrm{c}$ & 180 & 5'-GGTGGAGGCATCATAGGTAAT-3' \\
\hline
\end{tabular}




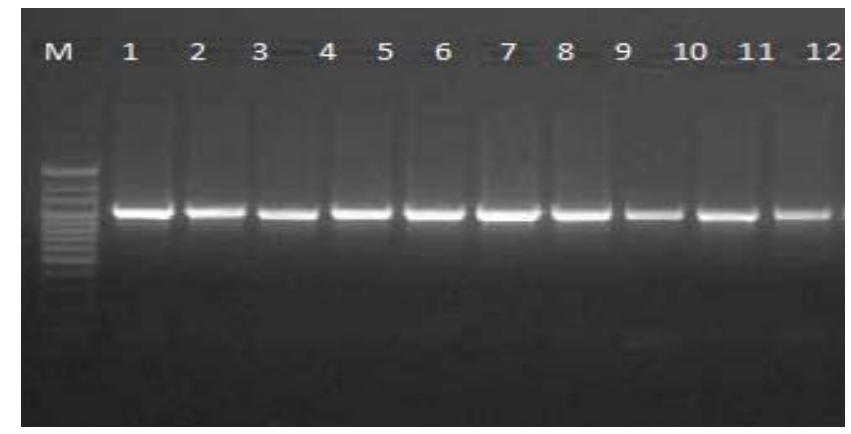

Fig.1:- Agarose gel electrophoresis of genomic DNA isolated from soybean genotypes were grown in Aurangabad (MS) .DNA loaded in 1\% Agarose gel and separated by electrophoresis for $90 \mathrm{~min}$ at $50 \mathrm{~V}$, then visualized by ethidium bromide staining with transillumination. Respectively; Lane I-1kb M, Lane II to Lane XII-genomic DNA isolated from soybean genotype viz. 1. (GENO-1), 2. (GENO-2), 3. (GENO-3), 4. (GENO-4), 5. (GENO-5), 6. (GENO-6), 7. (GENO-7), 8. (GENO-8), 9. (GENO-9), 10. (GENO-10), 11. (GENO-11), 12. (GENO-12)

\section{Digestion of DNA:-}

The restriction enzyme recognizes a unique, specific sequence of, usually, 4-6 base pairs (bp) in length, termed a restriction site, where the enzyme cuts (restricts) the DNA. In general, restriction sites will occur throughout the genomic and, consequently, application of the enzyme to total genomic DNA (Restriction of DNA) results in its conversion into millions of fragments. The frequency of restriction sites will vary depending on both the restriction enzyme and on the genome.

\section{Polymerase Chain Reaction Amplifications:-}

Here, in study two primer pairs were used for PCR amplification. We performed different PCR optimizations of the $\mathrm{PCR}$ reaction mix and conditions for each primer pair.

\section{SPA/SPB Primer Pair:-}

Works carried in two tubes of a total volume of $25 \mu \mathrm{l}$. The tubes contained $2 \mu \mathrm{l}$ of genomic DNA, $0.2 \mu 1$ of each primer, 2.5 $\mu 1$ 10x PCR Buffer, $3.5 \mu \mathrm{l}$ of $50 \mathrm{mmol} / 1 \mathrm{MgCl} 2,2.5 \mu \mathrm{l}$ of $10 \mathrm{mmol} / 1 \mathrm{dNTPs}$, and $0.3 \mu \mathrm{l}$ of Taq DNA polymerase. The program was initiated on Bio-Rad PCR amplifier with 5 min of denaturation, followed by 10 cycles of amplification with denaturation for $15 \mathrm{sec}$ at $94^{\circ} \mathrm{c}$ first annealing for $20 \mathrm{sec}$ at $54^{\circ} \mathrm{c}$ and extension at $72^{\circ} \mathrm{c}$ for 15 sec; followed by 40 cycles of amplification with denaturation for $1.5 \mathrm{~min}$, second annealing for $1.5 \mathrm{~min}$ at $61^{\circ} \mathrm{c}$, an extension at $72^{\circ} \mathrm{c}$ for $1 \mathrm{~min}$, and final elongation at $72^{\circ} \mathrm{c}$ for $5 \mathrm{~min}$.

\section{LE5/LE6 Primer Pair:-}

Works carried in two tubes of a total volume of $25 \mu$ l. The tubes contained $2 \mu 1$ of genomic DNA, $0.2 \mu 1$ of each primer, $2.5 \mu \mathrm{l} 10 \mathrm{x}$ PCR Buffer, $3.5 \mu \mathrm{l}$ of $50 \mathrm{mmol} / 1 \mathrm{MgCl} 2,2.5 \mu \mathrm{l}$ of $10 \mathrm{mmol} / 1 \mathrm{dNTPs}$, and $0.3 \mu \mathrm{l}$ of Taq DNA polymerase. The program was initiated on Bio-Rad PCR amplifier with $5 \mathrm{~min}$ of denaturatuion, followed by 10 cycles of amplification with denaturation for $15 \mathrm{sec}$ at $94^{\circ} \mathrm{c}$ first annealing for $20 \mathrm{sec}$ at $55^{\circ} \mathrm{c}$ and extension at $72^{\circ} \mathrm{c}$ for $15 \mathrm{sec}$; followed by 40 cycles of amplification with denaturation for $1.5 \mathrm{~min}$, second annealing for $1.5 \mathrm{~min}$ at $53^{\circ} \mathrm{c}$, an extension at $72^{\circ} \mathrm{c}$ for $1 \mathrm{~min}$, and final elongation at $72^{\circ} \mathrm{c}$ for $5 \mathrm{~min}$

All amplification products $(10 \mu \mathrm{l})$ were electrophorised in $1.5 \%(\mathrm{w} / \mathrm{v})$ TAE Agarose gels containing $1 \mathrm{~g} / \mathrm{ml}$ ethidium bromide. The electrophoresis was run in TBE at 100v for 40min and DNA bands were observed under UV light and photographed by image system.

Fig.2. Specificity of the PCR method using the primer pairs SPA/SPB and LE5/LE6 to identify the DNA. Agarose Gel Electrophoresis of PCR products amplified from genomic DNA of soybean genotypes.

Lane I-100bp ladder size standard;

Lane II-Lane XIII- sample Genomic DNA PCR products of Primer Pairs Respectively as above. 


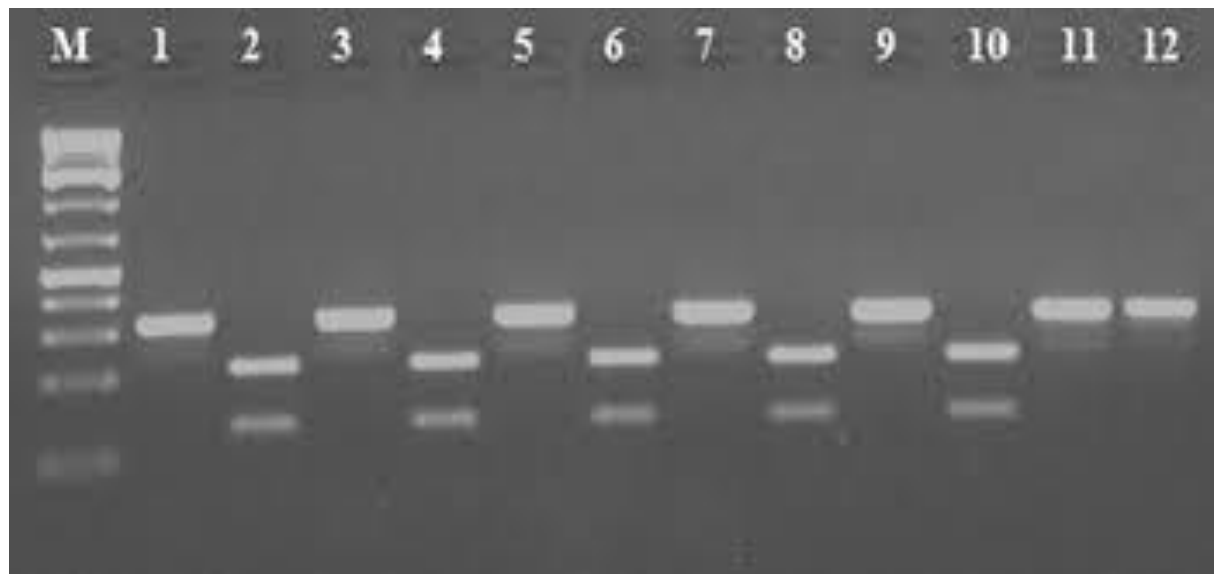

Fig 2:- Specificity of the polymerase chain reaction method using the primer pairs SPA/SPB and LE5/LE6 to identify the DNA Agarose gel electrophoresis of PCR products amplified from genomic DNA of Soybean genotypes. Lane I-100bp ladder size standard(M); Lane I,III,V,VII,IX,XI and XII sample genomic PCR product of $S P A / S P B$; Lane II,IV,VI,VIII and X sample genomic PCR product of LE5/LE6.

\section{PCR-RFLP Data analysis:-}

The PCR-RFLP analysis were performed in Agarose gel electrophoresis and its makes the banding pattern with high molecular weight DNA running fast in the lane; while low molecular weight run slow shown in the lane. The high molecular weight DNA was digested with an appropriate restriction endonuclease and the digest was fractioned by electrophoresis in 1\% Agarose gel by Shiraishi et.al. The banding patterns obtained from the ISSR markers were scored as present (1) and absent (0). The PCR-RFLP method enabled to identify nucleotides at each of the variable sites clearly reliable.

Each sample has amplified by using two primers for each fragment and it was treated as rearrangement in genome. The primers shows scoring and reproducibility were considered for the scoring of bands. The gel pictures were taken and documented to the computer by using alpha imager gel documentation system and each amplicon were measured by software. The dendrogram was plotted by using phylogeny free and tree view of DNA fingerprinting analysis tool (Dendrogram).

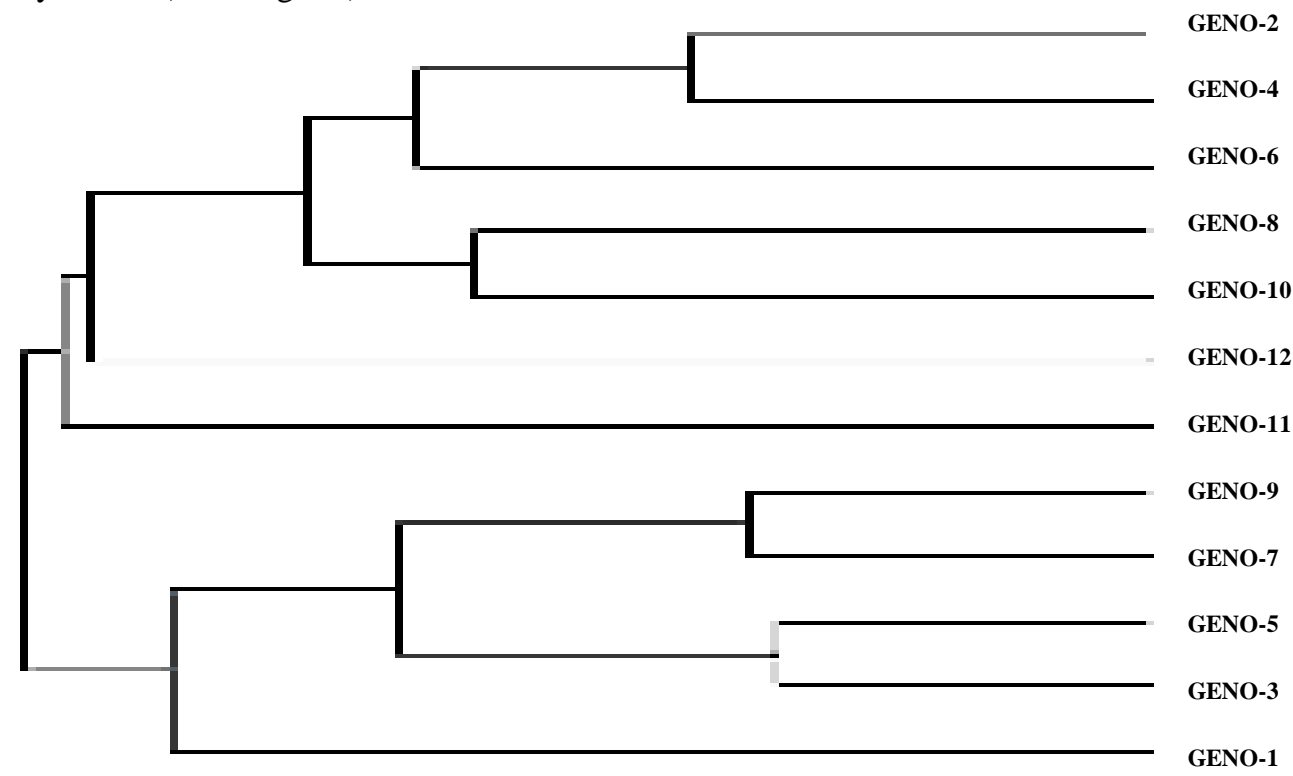

Fig 3:- Dendrogram based on bioinformatics phylogeny tool Free Tree and tree view of DNA fingerprint analysis. 


\section{Result and Discussion:-}

The selected samples of isolated DNA was run on $1 \% \mathrm{w} / \mathrm{v}$ Tris-Acetate EDTA gel were to check the quality of DNA sample have shown high molecular weight of DNA band (Fig.1). The amplification of genomic DNA of twelve selected genotypes using ISSR marker yielded total amplified 207 fragments were obtained while analysis of ISSR some fragments showed monomorphic and polymorphic in nature (Fig.2). In ISSR number of amplified fragments were ranged from $118 \mathrm{bp}$ to $320 \mathrm{bp}$. The PCR amplification using ISSR primers have potential to reproducibility of amplification of the product. The dendrogram analysis was carried out by using bioinformatics phylogeny tools free tree and tree view of DNA fingerprint analysis (Fig.3). Earlier the comparative analysis of genetic diversity was also attempted by using SNP, ISSR and RAPD markers in soybean genotypes, Vigna genotypes and Mung bean genotypes. The twelve Glycine max. (L.) Merrill derived genotypes were clustered in three groups. Cluster-I, II and III. The narrow genetic diversity identified among the soybean genotypes which derived from variety of JS-335. The present study may be the serve as the source of new alleles in soybean breeding programme.

\section{Conclusion:-}

The derived genotypes were identified for qualitative and quantitative characteristics. In cross breeding between the superior genetically different individuals which are having different gene of interest characteristics rather than involving individual belonging close relative genetic group. The analysis reported that in the present study could be useful to the selection of screened individuals for cross breeding purpose.

\section{References:-}

1. H.C.Vural (2010): Genetic identification of soybean [Glycine max (L.) Merr.] Growing in Turkey for Molecular Breeding using Molecular markers; Biotechnology \& Biotechnological Equipment; ISSN: 13102818.

2. P.Tanya*, P.Srinives*et.al; (2001): Evaluation of Genetic Diversity among Soybean Genotypes Using SSR and SNP; Korean Journal of Crop Sciences 46(4): 334-340.

3. Pardhe Deepak D.*, Satpute Rajendra A. (2011): A comparative Analysis of Genetic Diversity in Genus Vigna savi Genotypes using ISSR; International Journal of PharmTech Research CODEN (USA): IJPRIF, ISSN: 0974-4304, Vol.3, No.1, pp464-470.

4. Giriraj Kumawat, Gourav Singh et. al;(2015): Molecular Characterisation and Genetic Diversity analysis of Soybean (Glycine $\max (\mathrm{L})$ Merr.) germplasm accessions in India;Physiology and Molecular Biology of Plants;2015 Jan;21(1): 101-107.

5. Anchal Bisen, Dhirendra Khare et. al ;( 2015): SSR analysis 38 genotypes of Soybean (Glycine max(L) Merr.) genetic diversity in India ;Physiology and Molecular Biology of Plants;2015 Jan;21(1): 109-115.

6. M.Sesli and E.D.Yegnoglu (2010): Compare various combinations of similarity coefficients and clustering methods for Olea europaea sativa; Scientific Research and Essays August 2010, Vol.5 (16), pp.2318-2326.

7. Gu-wen Zhang, Sheng-chun Xu et.al; (2013): Determination of the genetic diversity of vegetable soybean [Glycine $\max ($ L.) Merr.] using EST-SSR markers; Journal of Zhejiang University Science B.2013 April;14(4): 279-288.

8. Alonso JM, Ecker JR (2006): Moving forward in reverse: genetic technologies to enable genome-wide phenomic screens in Arabidopsis. Nat Rev Genet 7: 524-536.

9. Waugh, Leader DJ, McCallum N, Caldwell D (2006): Harvesting the potential of induced biological diversity. Trends Plant Sci.11:71-79.

10. Kuromori T, Takahashi S, Kondou Y, Shinozhaki K, Matsui M (2009): Phenome analysis in plant species using loss-of -function and gain-of-function mutants. Plant Cell Physiology 50:1215-1231.

11. Akkaya, M.S; A.A.Bhagwat and P.B.Cregan (1992): Length polymorphisms of simple sequence repeat DNA in soybean. Genetics 132:1131-1139.

12. Akkaya M.S; R.C.Shoemaker, J.E.Specht et.al;(1995): Integration of simple sequence repeat DNA markers into a soybean linkage map. Crop Sci.35:1439-1445.

13. Brown S.M. (1999): Snapping up SNP. Biotechniques 26(6):1090-1094.

14. Brooks A.J.(1999): The essence of SNP. Gene 234:177-186.

15. Powell W, M.Morgante, C.Andre et.al;(1996): The comparison of RFLP,RAPD,AFLP and SSR (microsatellite)markers for germplasm analysis.Mol.Bre.2:225-238. 
16. Diwan N., and P.B.Cregan (1997): Automated sizing of fluorescent-labeled simple sequence repeat (SSR) markers to assay genetic variation in soybean. Theor.Appl.Genet.95:723-733.

17. Morgante M. (1994): Genetic mapping and variability of seven soybean simple sequence repeat loci. Genome 37:763-769.

18. Lagerkrantz U, H.Ellegran and L.Anderson (1993): The abundance of various polymorphic microsatellite motifs differs between plants and vertebrates. Nucleic acids Res.21:1111-1115.

19. Maughan P.J., A.S.Maroof and G.R.Buss(1995): Microsatellite and amplified sequence length polymorphisms in cultivated and wild soybean. Genome 38:715-723.

20. Gyapay G.J., Morissette A. et.al;(1994): The 1993-94 Genethon human genetic linkage map.Nat.Genet.7:246249.

21. Schlotterer C. and D.Tautz (1992): Slippage synthesis of simple sequence DNA. Nucleic Acids Res.20:211215.

22. Smith G.P.(1976): Evolution of repeated DNA sequences by unequal crossover Science.191:528-535.

23. Yanagisawa T., M. Hayashi , A.Hirai, K.Harada (1994): DNA fingerprinting in soybean (Glycine $\max ($ L.) Merrill.) with oligonucleotide probes for simple repetitive sequences. Euphytica 80:129-136. 